\title{
Evaluating National Socialism as a "True” Fascist Movement
}

\author{
Angelo Nicolaides \\ HOD Department of Hospitality, Tourism and PR Management, Vaal University of Technology, \\ Vanderbijlpark, South Africa \\ Email: Pythagoras13@hotmail.com
}

Received January $10^{\text {th }}, 2013$; revised February $8^{\text {th }}$, 2013; accepted February $18^{\text {th }}, 2013$

\begin{abstract}
The terms "Fascism" and "Nazism" are often linked, and at times they are regarded as one and the same ideology. The question raised is what is the distinction between Fascism and National Socialism or Nazism? A closer look at the ideas of fascism and National Socialism reveals certain affinities and overlaps with other ideologies, like Socialism, Liberalism and Conservatism. Fascism had many contradictory strands and despite deep unresolved tensions between ideas of race, nation and state in both National Socialism and fascism, the former is regarded as a "true" fascist movement. This article strives to ascertain the main differences and similarities between National Socialism and fascism and to ascertain if National Socialism could be considered to be a "true" fascist movement.
\end{abstract}

Keywords: Fascism; National Socialism; Totalitarianism

\section{Introduction}

The popular view taken concerning the issue of National Socialism and Fascism is a paradox one, concerning the mixtures of populations which on the one hand, looks to a new fascist individual, and ultra-elitism and contempt for the masses on the other hand, and this in no way makes National Socialism any less fascist than say Italian Fascism. Even though there some intellectual confusions and a lack of coherence between $\mathrm{Na}$ tional Socialism and Fascism they undoubtedly belong to the same ideological family (Rocco, 1982: pp. 42-44). In both National Socialism and Fascism, ideas were combined with highly emotive xenophobic and vicious forms of Nationalism. The "roots of fascism are traceable to the antagonisms between growing industrial monopolization and the democratic system" (Marcuse, 1973: p. 410). In order to allow monopoly capitalism to survive the working class opposition had to be neutralized. This meant that the existing democratic institutions could no longer serve as effective vessels for capitalism. For production to continue and profits to be kept up, totalitarian terror was required. This was the case in both National Socialism and Fascism. They were both used to repress the working class in the interests of big business, banks and various other major financial concerns. Both National Socialism and Fascism were mass movements of middle class reaction against Socialism and Liberalism in a period of serious political and social upheaval and crisis in Europe (Morgan, 2003: pp. 17-25).

\section{Origins}

The origins of the Third Reich were to be found in the eco The origins of the Third Reich were to be found in the economic destabilization of the 1920s. The twenties modernization wave broke up the "old" politics and created political space for new right-wing movements, except among industrial workers and the unemployed who were the "most immediately dependent on modernization" (Betz, 1994: p. 25), and failed to rally to the Italian Fascists and German Nazis in nay great numbers.
The Nazi and Fascist states were "propelled towards ever more radical measures by their own inherent instability" (Mason, 1990: p. 49). As F. L. Carsten remarked: “There was no 'Fascism' anywhere in Europe before the end of the First World War" (Carsten, 1980: p. 63). Ernst Nolte in his Three Faces of Fascism, more or less concurs with Carsten's view. Hugh Trevor-Roper commented that: "The public appearance of Fascism as a dominant force in Europe is the phenomenon of a few years only. It can be precisely dated. It began in 1922-1923 with the emergence of the Italian Fascist Party... it came of age in the 1930s in Germany... it ended in 1945 with the defeat of two dictators" (Trevor-Roper as quoted in Woolf, 1968: p. 18).

Fascist and National Socialistic thought also originated in terms of the Communist view, as "the openly terroristic dictatorship of the most reactionary, most chauvinistic and most imperialist elements of finance capital” (Turner, 1975: p. 119). The psychological character of certain classes, especially the lower middle class and socially deprived adolescents after the First World War in Italy and Germany also favored the growth of Fascism and National Socialism. Richard Koenigsberg in Hitler's Ideology: a Study in Psychoanalytic Sociology, also noted that "Hitler's ideology offered 'a means whereby his fantasies might be expressed and discharged at the level of social reality"” (Koenigsberg, 1975: p. 85). The lower middle classes in Germany and Italy after the First World War, suffered alienation, self-hatred and loss of security, which allowed them to develop sadistic traits of character which moulded the authoritarian personality (Laquer, 1979: pp. 465-467). However, neither Fascism nor National Socialism (Nazism), was classbased. In fact, Fascism always maintained that it was a national ideology. It rejected class struggles and class antagonisms and was "leftist" in orientation in terms of propaganda that was portrayed about it. This is why it was able to achieve what it did and it appealed to all social classes. It was mainly the working classes though that joined its ranks. In order to review the degree to which Italian Fascism characterizes a combination of aspects of nationalism and socialism, it is critical to differenti- 
ate between the political ideologies and how they were interpreted in different settings.

\section{In Italy}

When the Italian Fascist movement was created at the meeting of the Fasci di Combattimento in Milan on March 21st 1919, Mussolini and his then handful of supporters regarded the new movement as a left wing challenger for the working class votes which were at that time being handed to the Italian Socialist Party (PSI). This primary Italian Fascist movement included a combination of socialists who supported Mussolini, nationalists, forward thinkers, national syndicalists and war veterans from the First World War. Ideologically viewed then, Fascism developed out of the convergence of these groups and predominantly around the belief that Italy could and should be regenerated to its classical glory. The combination of different systems of ideological belief or practice namely, nationalism and socialism into what Mussolini described as "National Socialism" or Fascism was what resulted in Italy. The Marxists view of Italian Fascism was that it was the final drive of a rapidly collapsing middle class in its frantic effort to hold onto its strong socio-economic position in a scenario where the working class was rapidly gaining ground. The Fascists undoubtedly included many from the middle class in their ranks but they also incorporated the working classes and wealthy aristocrats.

Michael Mann, who is a Marxist historian, stated in his book Fascists, that the rise of right-wing authoritarian movements between the two world wars is to be understood as "nationstatism building not a cage but a concentration camp". This interpretation is essentially at odds with the Marxist interpretations of Fascism. Marxism per se, regards Fascism as a brutal endeavor to preserve capitalism from the challenges of leftwing mobilizations directly after World War I. Mann is also averse to regarding Fascism as a totalitarian "political religion" which emerged as a reaction against modernization and democracy. By the late 1930s, the basic thought was that Fascism and National Socialism was an aspect of a moral and religious crisis in Western civilization and while most of Europe passed through challenging economic times in the period between the wars, Fascists did not try to seize power in countries where the state had well-established democratic institutions and a strong foundation for infrastructural control. Benedetto Croce and R. Collingwood saw Fascism and National Socialism as a denial of human liberty. Croce argued that Fascism was a corruption of Italian liberty and stated that: "authoritarian governments endure only among decadent peoples” (De Ruggiero, 1927: p. 343).

Support by industrialists and Capitalists for Fascism was wide-ranging especially between different countries. A point of congruence amongst Fascist minded citizenry in countries where Fascism emerged was to be found in the powerful vested interests in the growth of the nation-state. The majority of the military and civil service personnel and especially the publicsector and manual laborers opted to become Fascists. Fascists recruited from both the ranks of the proletariat as well as the bourgeoisie. In this regard, G. L. Mosse regarded Fascism and especially National Socialism as a: "deeply rooted cultural malaise” (Mosse, 1966: pp. 15-34). De Felice, (1977: p. 176) expresses the opinion that Mussolini established a support base and also encountered many adversaries in every social class. If taken in a sociological context, Fascism was the result of a rapid development and modernization, or even the particular manner of industrialization in both Italy and Germany (Barrington, 1967: p. 88). Fascism was seen as a possible route to modernization, but when compared to Germany, industrializetion and modernization came late to Italy. The problem is that Germany was highly industrialized by the late 1920s, but Italy lagged relatively far behind. Then in terms of socio-economic criteria, Italian Fascism and Nazism should not be in the same category (Turner, 1975: p. 132). If rapid modernization is thus linked to Fascism then, in this respect, it does not adequately explain what happened in Italy and Germany.

Fascists were not in the least afraid of the revolutionary working-classes and in fact recruited vigorously from their ranks. In fact, in June 1914, Benito Mussolini personally took part in the violent and confrontational "Red Week" in which Fascists displayed there power. The advocates of Fascist ideology intended to display it as an amalgamation of nationalism and socialism. As early as the late 19th Century, nationalists including Corradini lambasted liberal Italian politicians on the basis that they had failed miserably in their feeble attempts to modernize the Italian economy. They had also not promoted Italian interests abroad in terms of colonial adventures and above all else, they had not protected the interests of the working classes.

Corradini maintained that Italy was a "proletarian nation" which had become embroiled in the international social Darwinist struggle for survival with far more dominant European states. Italy could only regenerate itself if class conflicts acme to an end and diverse classes in society began to work together to build national unity which was essential for economic growth and meaningful colonial expansion. The latter was especially needed as it would provide Italy with the much desired status of a great power. In 1938, Mussolini replaced the Chamber of Deputies with the Chamber of the Fasces and Corporations (Camera dei Fasci e delle Corporazioni). This Chamber was constituted of a number of delegates who were appointed by each of the corporations, plus a number of delegates appointed by the National Fascist Party.

Mussolini described the institutional transformations as follows:

"We have constituted a Corporative and Fascist State, the State of national society, a State which concentrates, controls, harmonizes, and tempers the interests of all social classes, which are thereby protected in equal measure. Whereas, during the years of demo-liberal regime, labor looked with diffidence upon the State, and was, in fact, outside the State and against the State, and considered the State an enemy of every day and every hour, there is not one working Italian today who does not seek a place in his Corporation or syndical federation, who does not wish to be a living atom of that great, immense living organization which is the national Corporate State of Fascism". (Lowell Field, 1968: p. 16)

The initial programmes of the Fasci di Combattimento were in a sense left-wing and the growth of Italian Fascism from 1920 and 1922 was essentially due to the expansion of the rural and provincial squads which often opted to use violence against socialist organizations and members as a means of defending especially upper and middle class interests. By 1922 the Fascists claimed that they would address the restraints of laissez faire capitalism and this would be by means of a Corporatist Third Way which was a middle-path between communism and capitalism. Industries were to be managed in terms of corpora- 
tist principles in which every industry would have corporatist organizations. The members of these bodies would represent employers and workers who were mentored by fascist officials. These would collectively make economic decisions to support the fascist cause by also improving the wages of workers. In practice however, the corporatist experiment was relatively unsuccessful and although there were some minor reforms the corporatist experiment by and large failed since Mussolini was under the control of wealthy financiers and industrial elites who continued to exploit the workers.

Venetian financiers, essentially controlled Mussolini, but in the eyes of the world he was perceived as Duce of the Fascists and Head of Government. For Mussolini, the fascist Italian was to be created on a par with the Renaissance Italian (Smith, 1975: p. 174). The Grand Council of Fascism (Gran Consiglio del Fascismo) was a very important organ and ostensibly idiomatic of the Fascist Party, the government ministers including the Presidents of the Senate and the Chamber and the commander of the Squadristi militias. A number of Fascist candidates were to be voted for and voters had to either accept or reject the notion of a unitary state. It was the Grand Council which was also tasked with submitting to the King the names of suitable candidates who could be elected as Head of Government. There were wide-ranging parliamentary limitations in Italy and the power of the fascist dictatorship grew as the independence of the judiciary became severely compromised. All political parties in Italy, other than the Italian Fascist Party were gradually abolished and the independent trade unions were replaced by fascist syndicates. Any other political groups were allowed to exist only if they remained uncritical of fascism and Mussolini. The media were very strictly monitored and censured and used predominantly as a puppet of fascist propaganda which promoted the idea that true identity could be found in the community of the nation and the nation preceded the individual. All class struggles could be counterbalanced by nationalism which was vehemently opposed to the liberal bourgeois conception of life, and both Germany and Italy as nations transcended division. It was nationalism that would prepare the nation for selfsacrifice, heroism and conflict. The bourgeois by comparison, tended to undermine these ambitions and wasted time and effort on the pursuit of materialistic desires and petty parliamentary politics. In Nazi Germany, the nation was imbued with a quasireligious aura, but this was not the case in Italian fascism. Ironically, it was the Grand Council which initially supported Mussolini that decided to oust him in July 1943. Mussolini tried to justify his ruthless regime through the requirement for efficiency and getting things done effectively in a weakening Italian state, but the Second World War soon exposed the vast military and logistical limitations of the fascist corporate state.

Fascism was thus a "conjunctural phenomenon" which combined heterogenous social class and generational support. Juan Linz expressed it as a "novel response to the crisis... of the pre-war structure and party systems" in both Italy and Germany (Laquer, 1979: p. 18). Nolte suggested that: "Fascism is antiMarxism which seeks to destroy the enemy by the evolvement of a radically opposed and yet related ideology" (Nolte, 1969: pp. 20-21). In his typology Three Faces of Fascism, originally published in German in 1963, Nolte subdivided it into four distinct stages of development. Pilsudski's Poland was regarded as a pre-Fascist state, while the Action Francaise was seen as a being in the early fascist phase of development. Mussolini's Italy was a "normal" Fascist state, while Germany's National
Socialists were regarded as extreme, hyper-nationalistic and almost radical Fascists (Nolte, 1969: p. 21). Nolte saw both Fascism and Nazism as having originated as "anti-Marxism", which set out to destroy the opposition by the use of virtually identical methods. Both were resistance to practical transcenddence and "anti-Christian Catholicism", but this ignores the fact that many were Catholics, especially in Italy. Both were driven by fear or "angst" of transcendence which in both Italy and Germany was directed against groups who symbolized transcendence. This was anticipated by Friedrich Nietzsche (Nolte, 1969: p. 440).

In Italian fascism, nationalism was more traditional and was in essence a form of patriotism and xenophobic imperialism. Fascism represented the seeking out of a "third way" between communism and capitalism which was intended to free society from the alienation of an industrial society and so liberal democracy and parliamentary government were rejected. The fascist movement was more characterized by what it stood against than what it stood for.

\section{How Were Fascism and Nazism Totalitarian in Nature?}

A totalitarian state is one in which the leadership has total authority and control over every aspect of the lives of citizenry. There is neither public nor private life and a dictator or ruling elite who use terror to subdue the masses. In a totalitarian state, propaganda is used extensively to control the hearts and minds of people. This was the case in both Fascist Italy and Nazi Germany. In both states all the individual liberties that liberals' tended to value, were heavily reduced. Only total obedience to the totalitarian state would serve the national interests. The fascist totalitarian state was dominated by the political elite and especially by Mussolini. Fascists based much of their theories on the work of the German philosopher Nietzsche and political scientists including Pareto, Mosca and Michels. Mussolini, Gentile and Primo de Rivera admitted that their vision of the state was totalitarian. Hitler shared this vision but linked it to the notion of control by force. Freedom was not individualistic but rather coincided with the purpose of the state.

The Nazi state was internally chaotic with no real top-down control and the Nazis worked with an existing state bureaucracy, many of whom only joined the ranks of the Nazis in 1939. The S.S. and other militarized elements worked in tandem with the state police and the army. Hitler had total control in this "organizational jungle” (Broszat, 1981: p. 358). Hitler and Mussolini thus had vital roles in their respective totalitarian states. A stated by Gentile: "It is always the few who represent the selfconsciousness and will of an epoch" (Gentile, 1928: p. 291). Despite the authoritarian nature of each state, both had traditionally entrenched interests and constantly changing alliances which forced Hitler and Mussolini to make concessions (Laquer, 1979: p. 411). Although Corporations were part of the ancient Volk in Germany, Italy had more complex relationships with the ideas of "syndicalism” and "corporation”. Mussolini's state would to a large extent direct and control syndicates for the ends of the nation but there was nothing comparable in Italy.

It was believed that both Mussolini and Hitler possessed the requisite political insights to effectively lead their respective countries and their political powers should thus be virtually unrestricted. National Socialism was undoubtedly a type of fascism but it was a lot more racially focused than Mussolini's 
Fascism. In both states, there were bureaucracies created to organize and maintain reigns of terror. The citizens of Fascist Italy and Nazi Germany would live untouched as long as they were loyal to Mussolini and Hitler respectively. Mass psychology was the methodology employed to control the citizenry. In Germany, the state could not be primary once the Fuhrerprinzep was created. It was Hitler as the Fuhrer who came to embody the sovereign authority of the state. Consequently all state authority was Fuhrer authority. In Italy, parties were considered to be compromising and they were merely stifling the national interest. Only propaganda would win them over (Schmitt, 1985: p. 50).

\section{Differences and Similarities between Fascism and Nazism}

The most profound difference between Fascism and Nazism was the centrality of the race issue. In the case of Nazi Germany there was a strong Volk tradition whereas in Italian fascism this is absent. The Germanic Volk factor alienated French Fascists like Drieu de Rochelle or Spanish Fascists like Primo de Rivera and even Mussolini. The latter referred to Germany in the 1930s as a "racialist lunatic asylum" (Mosse, 1966: p. 314). Italian Fascists never reached the intense levels of antiSemitism that prevailed in Germany. Another distinguishing mark is the intensity of terror and controlled violence which was markedly less in Italy (Turner, 1975: p. 17). The Italian Fascists vindicated their desire for colonialist expansion into parts of Africa, for example, in terms of their perceived racial superiority relative to the Africans and also gradually adopted a greater anti-Semitic mentality as their alliance with Hitler developed. Human nature assumed an interesting character in both Fascism and Nazism. Many young fascists were encouraged to think of violence in almost romantic terms. Violence is what linked the individual with the unconscious and it encouraged the "hero" idea of the Übermensch. Ultimately the idea of the Übermensch provided a strong theoretical basis for Fascism in Italy. Proponents of Fascism used Nietzsche's "Übermensch" or "superman" notion to validate their behaviour. Friedrich Nietzsche had reasoned that some members of humanity were endowed with a superior will and imagination, and as a consequence of this would as a matter of course, tend to dominate society and ruler the weaker masses. Unconditional inequality was biologically determined and irremovable and all Nazis accepted an inequality of races. The Aryan who was at one with the landscape and fellow Aryans, was considered superior in all respects to Jews, Slavs and Negroes. Hitler described Aryans as the "genius" race, but some Aryans were born to be superior to others. The genius or hero-figure could allow great things to be accomplished by peoples through his efforts. As Hitler put is: "The progress and culture of humanity are not a product of the majority, but rest exclusively on the genius and energy of the personality” (Hitler, 1939: pp. 310-313).

A related point about genius or leader figures was made in Italian fascism but it was not premised in accounts of either racial or biological genius, but rather on the interpretation of the sociological writings on elitism of inter-alia, Gaetano Mosca, Robert Michels and Vilfredo Pareto. It was these writers who assisted the generation of suspicions concerning parliamentary democracy which were rife amongst fascists. The element of self-deluding pomposity and neurosis was also a strong feature of both Hitler's and Mussolini's visions of their own roles (Smith, 1975: p. 127). Mussolini regarded himself as a man excluded from communing with others as if it was a divine law. He even introduced the Roman salute instead of the handshake as he reviled any physical contacts (Smith, 1975: pp. 128-139). Since fascists believed that human nature was corrupted by liberal democratic ideals, change was necessary. In the case of National Socialism, this campaign was duty-bound to produce a "Volk-bound German man" (Pois, 1986: p. 70). Mussolini desired that the fascist Italian had to be unburdened of wrong ideas and be recreated to be on a par with the Renaissance Italian (Smith, 1975: p. 174). For Germans such as Rosenberg the Nazis, the Aryan already existed but had to be protected against racial mixing however for Himmler and the Waffen SS, the new German man had to be selectively bred for the future and inferior races had to be eliminated. This was a popular ideology and as Heiden (1939: p. 98) stated: “The great masses of the people did not merely put up with National Socialism. They welcomed it”.

This notion was developed into the idea of the "superman" by later Fascists and Nazis. The Fascists and Nazis also accepted that totalitarian dictatorships were justified, as only a superior leader could fully exemplify the collective will of the masses. Both Italian and German fascist writers referred to Fascism as a state of mind or way of being. Nazis often proclaimed that one should "think with the blood". The masses were for the most part viewed as being instinctual or herd-like and they could thus easily be manipulated by the superior few. Thus crude forms of social Darwinism combined with the doctrine of the Herrenvolk or "master-race". Mussolini believed that all people were untrustworthy and selfish while Hitler was distrustful of all and hateful to all (Bullock, 1962: pp. 30-38).

The Nazis believed, as Hitler had stated in Mein Kampf (My Struggle), that the Aryan Germans were the master race and where thus superior to all others and were especially far more advanced than the Jews. Fascists also asserted also that individuals are all fundamentally competitive by nature rather than collaborative, and both an individual and a nation are caught up in a social Darwinist fight for the survival of the fittest where the "end justifies the means" in a Macchiavelian type approach. A number of fascists argued that it was only possible for individuals to arrive at their full potential through there physical participation in an often brutal struggle against both domestic and international opponents. Consequently using violence to crush any domestic political opponents is acceptable, as is resorting to war in order to achieve desired foreign policy objectives. Little attention was given outside Germany to the issue of living space or Lebensraum. This lay behind Hitler's foreign policy for the eastward expansion of Germany into Russia and the ultimate decimation of the Slavonic races. By contrast, Italian expansion was usually perceived in terms of European imperialism. In Germany it was linked almost obsessively to the issue of race since National Socialism was irrationalist and everything was judged from the perspective of race (Nolte, 1969: pp. 570-575). The German state was subservient to the Volk and to the racial issue, but in Italy, the Fascist movement strove towards rational modernization. In both Fascism and Nazism there were marked subdivisions. Alexander de Grand, in his study on Italian Fascism, speaks of conservative, technocratic, national, syndicalist and Squadrismi typologies of fascism. Nolte speaks of pre, early, normal and radical fascisms. This gradual evolving of National Socialism and Fascism is another link between them (Roberts, 1979: p. 318). 
Both National Socialism and Italian Fascism sought to bring about national and social unity in single-party systems which were highly totalitarian in nature. In fascism, politics took priority over economics and the focus was on the nation. Economics was thus determined by national objectives. In both National Socialism and Italian fascism, economic practices were a combination of socialist and liberal policies. The corporate state would integrate employers and employees in Italy and politics as expressed in the nation state. This was considered to be spiritually as well as morally superior to economics. In the case of National Socialism, race and Volk occupied the key position in thinking. In both Germany and Italy, the idea was for self-sufficient economy gathering its economic resources for the national ends. In the case of both states it was linked to the war footing in the 1030s. In Germany from 1936 onwards, the aim was for economic self-sufficiency in preparation for international conflict (Bullock, 1962: pp. 358-359).

The main ambiguity of both the German and Italian fascist regimes was that they used "a battery of economic controls to which left-wing governments, outside the Soviet Union, could still only aspire to". Yet the beneficiaries of these proposals were groups which supported more right-wing parties (Milward in Laquer, 1979: p. 411). Sternhell explains the development of fascist ideology in both Italy and Germany as a logical and reasonable response to the pervading practical political circumstances. The hatred for the bourgeois order and hatred of their values is a visible theme in both Italian fascism and Nazism (Sternhell, 1994: pp. 93-99).Certainly both Hitler and Mussolini appeared to have very little interest in economic theories, as long as their nationalist and imperialist ambitions could be underpinned. As Mosse noted on National Socialism: "It nationalized when it wanted to nationalize... It allied itself with big business when it wanted such an alliance", overall it seemed to lack any specific economic commitment (Sternhell, 1994: pp. 93-99). Fischer (1996) stated: "In the past fifteen years, the long-entrenched thesis that National Socialism represented the revolt of the Mittelstand (the middle-class, bourgeoisie) has undergone decisive revision. Although few historians would deny the Nazi party's success among the German middle classes in recruiting party members and drawing voters, sophisticated statistical work, much of it drawn from newlyexplored regional archives, has shown that the Nazi constituency was much more diverse than once imagined. Recent scholarship now argues that support for the Hitler movement extended to all social classes. Moreover, although the Nazi party performed especially well in Protestant regions, it did not fail to attract Catholics. In short, National Socialism evolved into a genuine Volkspartei (party of the nation) that transcended the class and milieu-based politics of the Weimar period...”.

In the area of Fascist attacks on intellectualism, it is difficult to isolate Fascist themes or ideologists although the Italians had Giovanni Gentile who "built" up much of the doctrine of fascism for Mussolini. The National Socialists did not have anyone as distinguished in their ranks. The National Socialist interpretation of the term "social" was distinct from that of the Italian fascists as the former focused on the racial Volkisch dimension rather than on the state. An individual was constituted through the community which was constituted in terms of racial soul (Volkseele). Nature was regarded as a life force which gave both meaning and purpose to humans and their Volk (Mosse, 1978: p. 15). It was the emotive, instinctive life of people that linked them to their Volk and also to their inner life-force of nature. People could be glorified, therefore, according to their oneness with nature, and not through their dominance over it. Unlike the Italian fascists, the Nazis celebrated in a bogus, and almost mystical sense, peasant life, country landscapes and nature. It was the landscape which imbued people with their inner life force. Hitler's love of animals and the fact that he was a vegetarian are related to this standpoint. As in the case of leaders in Nazism, the leadership membership of the Fascist movement was derived from amongst war veterans and in particular, former commissioned and noncommissioned officers. Members were also recruited from the ranks of the white collar workers and the educated middle class.

Madden (1987) has shown that National Socialists emanated from all social classes in large volumes. Fischer (1978) also assessed the class orientation of the members of the Sturm Abteilung (S.A., Stormtroopers or Brownshirts) and uncovered that "the workers are over-represented in the S.A." (p. 140). From $1933-1934$, some $69.9 \%$ of the S.A. emanated from the working class compared to $53.2 \%$ from the German population in general. Italian Fascists as well as Nazis criticized liberal democracy on the grounds that political parties and various pressure groups appealed to the selfish egoism of certain people and increased social conflicts at a time when national unity was desirable. Both Hugh Trevor-Roper and Ernst Nolte view fascism as a result of tyranny and megalomania on the parts of Mussolini and Hitler respectively. Alan Bullock states that fascism "was to Hitler the instrument of his ambition" (Bullock, 1962: p. 237).

\section{Conclusion}

Both Fascism and Nazism were highly totalitarian in nature. Both had one powerful leader, who came to epitomize the general will of the nation. The leaders felt at ease in invading all areas of both public and private life and this was justifiable as it supposedly served the "greater good". Each state sought to bring about national and social unity in single-party systems which were totalitarian in nature and although there were some differences between fascism and National Socialism, there were enough similarities between them for them to be treated as part of the same movement in which the masses could be won over by extensive propaganda (Mosse, 1978: p. 128). Sternhell is of the opinion that Nazism was not "truly fascist" on account of its form of racism (Sternhell, 1994: pp. 93-97) whereas R. de Felice viewed Italian fascism as being fundamentally different from Nazism on account of Nazism's atavistic tendencies (De Felice, 1977: pp. 20-26). Philip Moran sees Italian fascism and German National Socialism as belonging to the same "family" as both were mass movements of the "middle-class reaction against liberalism and socialism in an era of severe political and social crises” (Morgan, 2003: p. 8). This is somewhat distinct from the view of Reinhard Kuhnl who asserts that "National Socialism was 'fascist' but was also its own movement with its own criteria which are not directly connected to capitalism or to capitalist desires" (Mosse, 1996: p. 48) and had an "unquestionable revolutionary nature” (De Felice, 1977: p. 191). Vajda, in Fascism as a mass movement, sees Italian fascism and National Socialism as original European phenomena which expressed the traditions and tendencies of Europe and should thus be understood as part of the development of the ideological and political structure of the West. Both are bourgeois and both are 
equally opposed to liberalism each had a bourgeois form of power with aggressive expansionist aims against people with in similar economic and cultural levels as well almost identical social systems (Vajda, 1976: p. 26). In both, fascism appealed to individuals and portions of the mainstream elite whom it promised to serve more efficiently and effectively than the ruling existing parties. There were without doubt great linkages between fascism and National Socialism (Turner, 1975: pp. 84-86). While they have similarities and differences, the differences do not preclude National Socialism from being viewed as a truly Fascist movement. Essentially the congruence between them far outweighs any dissimilarities. Critically, in both, violence was a preferred tool to use in harnessing support and in obtaining desired objectives.

Even though National Socialism was unique in that it had the Aryan myth and racism and extreme anti-Semitism based on supposed biological superiority. Some Germans saw Jewishness as a cultural or spiritual problem, but to others it was regarded as a racial problem. It was often associated with the bourgeois life and even Bolshevism. The Jews soon became the central focus point of nationalistic hatred in Germany. The frustration with their lives drove many Italians and Germans to seek new strengthening of their nations in what became hypernationalistic drives to monopolize politics, social organization and even education and cultural affairs (Turner, 1975: pp. 44-52). It is evident that both Italian Fascist and German Nazi leaders were able to rise to power as the existing leaders were unable to halt the threat, perceived or real, from the radical left. They were essentially unable to forge any consensus top diffuse the threat from the radical left and attract support to win a majority in the parliaments, and so fascist movements tended to develop in nations with strong left-wing movements (Carsten, 1980: p. 233). The use of terror and violence in fascist Italy and Nazi Germany against enemies of the state and the removal of pluralism in both states further emphasized that they were very similar in orientation. Both states used mass psychology and extensive propaganda campaigns to great effect. Both states idolized their leaders manipulated the masses. There is no doubt that National Socialism was a variation of Italian fascism and a true fascist movement.

Both National Socialism and Italian fascism were revolutionary in nature and were mass movements that mobilized the populace and both vilified the west as a plutocracy and aimed at destroying the existing order so that a Volk or nation could finally triumph and both hated traditional elites. Renzo de Felice sees Italian fascism as emanating from a radical left-wing enlightenment (De Felice, 1977: pp. 14-33). Both were inhuman as they negated the freedom and dignity of the people and each was linked to the notion of adaptability and was ascribed to certain socio-economic conditions in countries transforming into industrial societies. The researcher believes that there are thus enough similarities between National Socialism and fascism per se for us to categorize them as being in the same "family' of ideology and National Socialism was thus a truly fascist movement". "To the historian fascism is Janus-faced. One face looks forward, in the spirit of the Enlightenment, to the rational control and direction of human life; the other face looks back- wards to a much simpler more primitive life, when men struggled to live”, National Socialism fits the bill (Skidelsky, 1975: p. 288).

\section{REFERENCES}

Betz, H. G. (1994). Radical right-wing populism. New York: St. Martins.

Broszat, M. (1981). The hitler state. London: Longman.

Bullock, A. (1962). Hitler: A study in tyranny. London: Konecky \& Konecky.

Carsten, F. L. (1980). The rise of fascism. London: Batsford.

De Felice, R. (1977). Interpretations of fascism. Cambridge: Harvard U.P.

De Ruggiero, G. (1927). The history of European liberalism. Oxford: Clarendon Press.

Fischer, C. J. (1978). The occupational background of the S.A.'s rank and file membership during the depression years, 1929 to mid-1934. In P. Stachura (Ed.), The shaping of the Nazi state. London: Croom Helm.

Fischer, C. J. (1996). The rise of national socialism and the working classes in weimar Germany. Oxford: Berghahn Books.

Gentile, G. (1928). Philosophic basis of fascism. Milan: Foreign Affairs 6.

Heiden, K. (1939). One man against Europe. Penguin: Harmondsworth, Middlesex.

Hitler, A. (1969). 1939 Mein Kampf. London: University of Chicago Press.

Koenigsberg, R. (1975). Hitler's ideology: A study in psychoanalytic psychology. New York: Library of Social Sciences.

Laquer, W. (1979). Fascism: A readers guide. London: Routledge.

Lowell Field, G. (1968). The syndical and corporative institutions of italian fascism. New York: AMS Press.

Madden, P. (1987). The social class origins of Nazi party members as determined by occupations, 1919-1933. Social Science Quarterly, 68, 263-280.

Mann, M. (2004). Fascists. Cambridge: Cambridge University Press. doi:10.1017/CBO9780511806568

Marcuse, H. (1973). Reason and revolution. New York: Oxford University Press.

Morgan, P. (2003). Italian fascism 1919-1945. New York: Taylor \& Francis. doi:10.4324/9780203448229

Mosse, G. L. (1966). The crisis of German ideology. London: Weidenfeld \& Nicolson.

Mosse, G. L. (1978). Nazism: A historical and comparative analysis. Oxford: Basil Blackwell.

Nolte, E. (1969). Three faces of fascism. New York: Mentor.

Pois, R. (1986). National socialism and the religion of nature. London: Croom Helm.

Roberts, D. (1979). Syndicalist tradition and Italian fascism. Manchester: Manchester University Press.

Rocco, A. (1982). The political doctrine of fascism. Denver: Alan Swallow.

Skidelsky, R. (1975). Oswald Mosley. London: Macmillan.

Smith, M. (1975). Mussolini. New York: Weidenfeld and Nicolson.

Sternhell, Z. (1994). The birth of fascist ideology. Princeton: Princeton University Press.

Turner, H. A. (1975). Reappraisals of fascism. New York: New Viewpoints.

Vajda, M. (1976). Fascism as a mass movement. New York: Palgrave Macmillan.

Woolf, S. (1968). European fascism. London: Weidenfeld and Nicolson. 